\title{
Conflict Resolution in the Context of Early Childhood Bilingual Education - towards a multicultural development
}

\author{
Resolução de Conflitos em contexto de \\ educação bilíngue infantil - em busca de \\ desenvolvimento multicultural
}

\author{
Daniele Gazzotti* \\ Stance Dual School \\ São Paulo - São Paulo / Brasil \\ Fernanda Liberali** \\ Pontifícia Universidade Católica de São Paulo \\ CNPq \\ São Paulo - São Paulo / Brasil
}

\begin{abstract}
RESUMO: Este artigo discute como crianças pequenas aprendem a lidar com conflitos sob uma perspectiva multicultural. Esse trabalho é baseado na visão de que, em um mundo com múltiplas demandas e perspectivas, as crianças aprendem a lidar com a vida de diversas maneiras o que permite que elas escolham em que se tornar. Os principais conceitos nos quais este artigo se baseia são: multiculturalismo, ligado ao multilinguismo e a multimodalidade, bem como intervenção colaborativa para a criação de zonas de desenvolvimento proximal e argumentação oral infantil. Os dados consistem em um episódio de uma situação de lanche entre crianças de dois anos de idade, transcrito multimodalmente, que mostra o desenvolvimento multicultural dessas crianças, pela maneira como elas lidam com a resolução de um conflito.
\end{abstract}

PALAVRAS-CHAVE: multiculturalismo, intervenção colaborativa, resolução de conflito.

ABSTRACT: This article discusses how young children learn to deal with conflicts from a multicultural standpoint. The present work is based on the view that, in a world of multiple demands and perspectives, children learn to deal with life in a variety of ways that will enable them to choose who they will become. The main underlying concepts of this article include: multiculturalism, linked to

\footnotetext{
*danigazzotti@hotmail.com

** liberali@uol.com.br
} 
multilingualism and multimodality, as well as collaborative intervention for the creation of zones of proximal development and children's oral argumentation. The data consists of a multimodally transcribed episode of a snack time situation among two-year-old children, showing the multicultural development of kids in their way of dealing with conflict resolution.

KEYWORDS: multiculturalism, collaborative intervention, conflict resolution.

\section{Introduction}

This article discusses the interrelationship between multiculturalism and the work with conflict resolution in Early Childhood Bilingual Education. The idea of studying conflict resolution was triggered by the perceived difficulties of both young children and adults to deal with children's conflicts, which frequently end up in non-verbal actions such as biting, pushing, hitting or pulling one another. This problem was noted by the researchers through their experience in the field of childhood education: Liberali, as a school consultant and teacher educator, and Gazzotti as a young children's teacher. The researchers realized that most of the educators who work with Early Childhood Education and PreSchool Education could not find the means through which to collaborate with children to solve daily conflicts by themselves, mostly due to a lack of time, an overload of activities to be accomplished with the kids or a disbelief in kids' potential to deal with problems autonomously. It was most common that teachers would solve the problems for the children rather than with the children. This issue became the main focus of the research conducted by Gazzotti, and supervised by Liberali, in Gazzotti's Master Studies, the results of which can be found in Gazzotti (2011).

This paper aims to go beyond prior research - as the implications of this autonomous work with conflicts, which took place in a Bilingual Education context - to the multicultural development of the kids. The aim is to investigate the implications and affordances of this environment for the children's process of multicultural development. To achieve this aim, we will discuss the concept of multiculturalism and collaborative intervention in conflict resolution through children's argumentation.

Sharing the view of authors such as Vygotsky, who considers human activity to be a transformation of both the cultural-historical-social environment and the subjects themselves, this research is a part of the studies developed by the Grupo de Pesquisa LACE study group, from Pontífice Uuniversidade Católica de São Paulo (PUC-SP), under the academic 
supervision of Maria Cecília Magalhães and Liberali. Through criticalcollaborative research, Grupo de Pesquisa LACE investigates how subjects constitute themselves and one another culturally, historically and socially, as well as how they act in and how they transform their environment.

Bearing in mind that education has the potential for major changes in society, applied linguists use and organize language in order to intervene and change unfair or conflicting situations, which is the central theme of this study. Part of the applied linguist's role is to create tools, with the socially oppressed, in order to expand their ability to think about, reflect on and use these tools in an attempt to transform this oppressive situation. In this study, the processes developed to solve conflicts in a collaborative way in a bilingual context are thought of as a means through which to develop multiculturalism.

Here, the word conflict is defined as a situation in which the social interaction between two or more individuals causes one of them to feel frustrated, uncomfortable or in pain. In addition, multiculturalism is understood through what Santos (2008) designed as the recognition and development of a plurality of human possibilities for one's integral participation in the world, which is achieved through a permanent dialogical engagement with the contexts of life. Moreover, it presupposes that each human being can systematically articulate, in a dynamic and horizontal manner, forms of self-knowledge, other-knowledge and inter-knowledge.

In multilingual contexts, such as those provided by bilingual schools, the two or more languages may play an impacting role in this articulation. The complex pluralism created by dealing with two or more languages and by their insertion in multiple cultures leads learners to deal with important metacognitive and metalinguistic processes that lead to a cultural and linguistic expansion. In Gazzotti's (2011) study, there was a main belief that, by solving conflicts, children would learn how to put themselves in a different position, become more critical citizens towards the world and learn how to act in order to change unjust situations. This result proved possible in her study; however, much more than that, the study hinted that this way of solving conflicts, in bilingual contexts, provided students with opportunities to expand their multiple possibilities of acting in the world both multiculturally and multilingually, which is the focus of this paper.

The data production for this study was developed by Gazzotti (teacherresearcher) with a group of twelve two-year-old Brazilian children who were having their first experience at school, as well as their first contact with the 
English Language, due to their immersion in a Bilingual School. At that age, children know very little about how to communicate feelings, how to interact with one another and how to use language as a tool to solve conflicts. The conflicts, mostly disputes, happened quite frequently, as children mostly recognized their own desire with disregard for the others. For example, if one child wants to play with a certain toy that is presently being used by someone else, this child would be unable to realize on her own that the object of his/ her desire is being used and, therefore, he/she cannot simply satisfy his/her desire by grabbing it. It is hard for young children not to have their immediate desires fulfilled and adult intervention is necessary for them to understand such a fact. In the context of this study, the educator, Gazzotti, took advantage of these recurrent disputes and helped children to reflect upon the situations, co-building knowledge about social interaction, language and emotions (GAZZOTTI, 2011).

The question we now want to address and discuss is: how did this procedure contribute to develop kids' multicultural development? To answer this question, we will first present the theoretical background for multiculturalism and collaborative intervention within the concept of conflict resolution. After, we will describe the process of research developed by Gazzotti in order to produce the data. We will then provide explanations on how we organized the transcription of the data in a Multimodal perspective and how we analyzed the data with the new perspective of observing the issue of multiculturalism through argumentation. We will then present some discussion on the data analyzed and interpreted. We will finally offer some considerations about the importance of this study to the practical and theoretical field of Multicultural Education.

\section{Theoretical Discussions}

In this section, we discuss the relationship between multiculturalism and intervention in conflict resolution through children's oral argumentation.

Nowadays, there is a clear consideration of the multiple representations of reality. These are evident in the ways in which the prefix "multi" has been connected to so many words that organize school life, for example: multiculturalism, multilingualism, multiliteracy, multimedia, multimodality and multidisciplinary. In this multiplicity of possibilities provided by the addition of multi, choice is created. There is a reversion of the certainty so acclaimed by previous views of life in which one way was the best way and 
should be followed by all (as in the Positivist perspective). Today the complexities of life demand that each and every person be prepared to deal with multiple problems, in multiple situations, with multiple people, with multiple backgrounds (LIBERALI, work in progress). In this sense, as stated by Kress and Van Leeuwen (2006, p. 36), new realities with multiple semiotic landscapes are brought about by social, cultural and economic factors which intensify the linguistic and cultural diversity within the boundaries of nation states and weaken boundaries within societies.

According to Cope and Kalantzis (2009), in a context of increased globalization, multilingualism, for instance, has become an increasingly significant phenomenon. In addition, the authors pointed out that differences within a language are not adequately taken into account. More specifically, concerning the English language as a world language, the authors adverted to the fact that there is an increasing perspective of multiple Englishes. However, education seems not to take this into consideration and not to address this issue with regard to teaching and learning processes. In a world where meaning is conveyed in multiple languages (English, Portuguese, French, Mandarim), through multiple medias (tablets, TV, radio, PC), with multiple modes (linguistic, visual, audio, gestural and spatial forms), it is essential that students learn to work multidimensionally. To deal with this phenomenon, the authors suggested the perspective of multiliteracy, focusing both on what and how the teaching - learning process would be developed.

In a sense, all this involves the fact that thinking is multiple. As Vygotsky pointed out (1934/2008), the thinking system is complex and expandable by the interrelation of people amongst one another. To work with multiple languages implies multiple possibilities of thinking and being in the world with others. The multiple interconnections between participants of different backgrounds provide all with chances to expand their limitations and to search for new territories. Multidimensional contexts help provide students with multiple and constantly shifting viewpoints from which they can gather possible future choices of choosing, performing and being, thus having not only a cognitive impact on the subject, but also an emotional one. Providing such a multidimensional environment may influence the psychological development of children and the development of their personalities: "The essential factors which explain the influence of environment on the psychological development of children, and on the development of their conscious personalities, are made up of their emotional experiences: 
[perezhivanie ${ }^{1}$ ]" (VYGOTSKY, 1934, p. 338). Working in this manner, the teacher and colleagues provide one another with a multiplicity of possible configurations, and, hence, with a multiplicity of ways in which they can relate to the reality they are depicting and constituting while constituting and transforming themselves mutually. Their strong relationship with each other and with the environment has an essential developmental perspective, because it is through this perezhivanie that they will be able to construct the future course of their development.

In a perspective of emancipatory multiculturalism (SANTOS, 2008), this is also the recognition of the plurality and the lack of neutrality of the choices of life. It also involves the ecological production of different types of knowledge that can intervene in the world, that is, a polyphonic perception of reality. It implies an attempt to search for the convergence in an understanding that the more plural we are, the more we need to learn and find ways to connect and create together. This relates to a strong attempt to constitute collective and individual subjects that are involved in the fight against all kinds of oppression.

The semiotic fields by which participants are guided, their contextual configuration (GOODWIN, 2000), enables them to mutually elaborate each other, creating new semiotic tools in a continuous process of change. Goodwin (2000) states that human language, cognition and actions consist of a situation in which multiple participants are attempting to carry out courses of action together with each other through talk, while attending to both the larger activities that their current actions are embedded within, and the relevant phenomena in their surroundings. Therefore, the analysis of language is seen as the connection of multiple semiotic fields that make actions more visible. In addition, it poses the discussions beyond the individual perspective to take

\footnotetext{
${ }^{1}$ The translator of the internet version of the text used in this quotation gives this explanation for the word perezhivanie: "The Russian term perezhivanie serves to express the idea that one and the same objective situation may be interpreted, perceived, experienced or lived through by different children in different ways. Neither 'emotional experience' (which is used here and which only covers the affective aspect of the meaning of perezhivanie), nor 'interpretation' (which is too exclusively rational) are fully adequate translations of the noun. Its meaning is closely linked to that of the German verb 'erleben' (cf. 'Erlebnis', 'erlebte Wirklichkeit')." (VYGOTSKY, 1934 , p. 354). In this article, we choose the expression emotional-cognitive experience as another way to understand it.
} 
into account the social aspect of the experience of the interlocutors, what in Vygotskian terms we could define as their perezhivanie.

According to the New London Group (1996/2000), when working with different languages, discourses, styles and approaches, learners have significant gains in metacognitive and metalinguistic terms as well as in terms of critical reflection on complex systems and interactions. Pluralism changes the nature of public responsibilities and rights. They need to be recognized, reflected and negotiated so that they complement and generate cultural and linguistic expansion. In this framework, people enter different lifeworlds and their identities become more complex, which emphasizes the importance of people belonging to multiple communities with multiple discourses and multiple identities.

As subjects, men and women are born and brought up in a historically developed society, which was built by thousands of collectively and historically built pieces of knowledge over time. Within this perspective, the subject is seen as a concrete human being, existing in a specific time and space, within a cultural-historical-social-economical-political context and, for this reason, s/he cannot be understood apart from such aspects that contributed greatly to his/her constitution. In addition, as s/he becomes aware of his/her environment and interacts with it, s/he transforms both him/herself and the environment.

Moreover, Vygotsky adds that one can only understand the human mind historically because it is created and produced through the participation in and through the internalization and externalization of historical-social forms of activity. In this manner, the subject's individual constitution is inseparable from his social history. This author (1930/1984) also believes that: if the school environment enables the raising of relations within the child's intellectual processes, one can only assume that the educator plays a crucial role in the development of such processes. In this study, the educator aims to collaborate to children's development by helping them to resort to language (Portuguese and English) and the act of reflecting as mediating tools in interpersonal relationships. Since this is done at a very early age when higher mental functions are being initially and intensively developed, these mediations enable children to interiorize such social methods of reasoning and begin to externalize them in such a way as to create new realities in their initial interaction with others.

Adding to this theory and highlighting the importance of language on the development of mental functions, Bakhtin (1929/1981) argues that 
children do not acquire a mother tongue. It is being immersed in one that enables the emerging of consciousness. For him, the concept language is only possible once considered inside a visual-verbal interaction among subjects. This linguist does not see language as a structure of forms and meanings but as a constitutive element which is inseparable from the subjects. That is, subjects constitute themselves by the language and in the language. In his studies regarding the development of utterance, he claims that because people live and are brought up in linguistic environments, which reflect different social experiences, no utterance is built up by itself, but rather by other utterances existing before it. If what makes consciousness emerge is the exposition to language and if language enables social interaction between subjects, one can understand that subjects, language and society constitute one another and are constituted by one another. One can also conclude that people's minds are raised in their contact with language, society and other subjects.

Both Vygotsky's and Bakhtin's theories point to the fact that the development of the subject's mental activity does not lie within the mind itself, but within the social grounds, in multimodal interactions with the world. In such a way, it is possible to understand that the subject's own identity is the product of this subject's social, multimodal and affective relations, and carries within itself the voices of other multimodal utterances that are a part of its constitution.

If one accepts that the development of consciousness and of higher mental functions (such as thinking and reasoning) are directly related to language and society and, therefore, to the subject's life experiences, then the processes of internalization and externalization in very young children are crucial to their development and the development of their personalities. The socially shared experiences become internally shared knowledge to which the child will turn when dealing with a similar situation. In other words, what was once done between people (a parent or teacher and the child) - interpsychological - becomes a part of the child's ways of reasoning - intrapsychological. The child internalizes her previous experience as a cultural method of reasoning and resorts to it when living a similar experience. Vygotsky (1933-1935) states that for very young children, "thinking is remembering", which happens through the repetition of experiences. That is to say that the child internalizes multiple tools, in turn learning to plan his/her activity mentally. $S /$ he then creatively externalizes new forms of acting in the world using these tools, which will involve the production of new artifacts and forms of uses. In a multimodal world, by 
internalizing, in multiple ways, multiple modes and multiple languages, the subject develops the possibility of externalizing an even greater number of multiple possibilities of future artifacts, in multiple modes, using multimedia.

This is very often perceived in play situations and in the daily dispute, which is the central theme of this article. Generally, the child reacts instinctively by expressing his/her emotions in processes, such as pulling the toy that another child has grabbed back to himself/herself, or by screaming, crying, biting, etc. After s/he experiences other forms of acting to solve conflicts, they may attempt to find other ways of solving disputes. For instance, Vygotsky (1934/2008) stated that, at a very early age, the developmental curves of speech and thinking cross one another in the child's mind, allowing the infant to enter a whole new stage of his/her development; a stage in which speech is necessarily related to mental activity and will help the child to anticipate his/her future actions. Thus, after language is interiorized, it also starts functioning as a tool for reasoning: "This leads us to another main and unquestionable fact: the development of thought is determined by language, that is, by its linguistic tools and by the child's cultural-social experiences" " (VYGOTSKY, 1934/2008, p. 62.).

Bearing this in mind, one can conclude that language is necessary for the intellectual development of the child, as it is considered the social means of reasoning, and the merger of language and cultural-historical-social experiences, which are essential factors of thought. For Vygotsky (1929), throughout development, children learn both to master the cultural aspects of social experience and forms of social behaviour that can be considered the cultural methods of reasoning. In this sense, if children are exposed to argumentative and reflexive processes when solving interpersonal conflicts, at the age in which the curves of development of speech and thinking start working together, this will eventually be internalized by the child as a cultural method of reasoning, collaborating to the child's psychological development, as well as to the development of his/her personality. If language is a determining factor in the development of thought, (VYGOTSKY, 1934/2008), the multiple languages and meanings to which the child is exposed within their speeches are crucial to the development of their thoughts and actions.

\footnotetext{
${ }^{2}$ Original Text: "Isto nos leva a outro fato inquestionável e de grande importância: o desenvolvimento do pensamento é determinado pela linguagem, isto é, pelos instrumentos linguísticos do pensamento e pela experiência sócio-cultural da criança” (VYGOTSKY, 1934/1987, p. 62 - our translation).
} 
The concept of the Zone of Proximal Development (ZPD) is directly related to, if not inseparable from, the concept of internalization and externalization of social actions, as described above. The idea portrayed by ZPD is that, in collaboration with one another, the subject is able to go beyond their immediate possibilities (NEWMAN \& HOLZMAN, 2002). In this sense, interaction between subjects is extremely important to the learning process. Through interaction with a peer, subjects can externalize and internalize different forms of actions, communicating and reasoning, thus going beyond their previous possibilities. Within this perspective, the educator does not wait until the child is old enough to do a certain activity he/she thinks is appropriate (like solving conflicts verbally) to expose the child to it. By exposing the child to certain activities and by allowing him/her to learn in collaboration with a peer, the child learns and subsequently develops. Here, one can see that learning guides development in a dialectical manner.

Magalhães (2007) expands the concept of ZPD by stating that it is a critical-practical transformative activity, a zone of creative action in which collaboration and critical thinking enables the creation of new possibilities. In this sense, an intervention to solve conflicts would be connected to the concept of ZPD in which the creation of new multiple forms of acting through the mediations are both a pre-requisite and the product of this zone.

In this article, we state that children, as subjects, constitute themselves through the relationship they establish with others and with the environment, and that their psychological development and the development of their identities are directly related to the cultural-historical-social context in which they are inserted. Therefore, we believe that a collaborative multicultural environment, which establishes a ZPD, can be seen as a tool to solve daily conflicts and as a place where the attempt to solve conflicts through argumentation is already a solution in itself.

Although it is not very common for adults to grant children argumentative value, much research in the area has found young children to be able to participate in argumentative situations. As pointed out by Ribeiro (2009), argumentative abilities begin to develop very early, when the child acquires the oral language and learns how he/she can both use and understand it. According to the author, kids begin to recognize and produce arguments when interacting with their family, friends and other people in the community. Children's argumentative possibilities have a three-fold development. First, they learn language and how to express themselves through it; second, they constitute themselves as subjects while doing so; and third, they develop their consciousness. 
The idea of motivating toddlers to resort to oral argumentation when dealing with disputes also, as stated by Leitão $\&$ Banks-Leite (2006), carries the idea that in the argumentation process different meanings are shared, negotiated and transformed, related directly to the concepts of ZPD described previously in this article. Thus, using argumentation to share and co-build new meanings is done as a cultural method of reasoning, fitting perfectly to the purpose of collaborative conflict resolution as opposed to crying or biting. It is a mediation tool which enables shared meanings to be expanded (LIBERALI, 2008).

\section{Context and Methodology}

This research was carried out in a bilingual school, located in the centre of São Paulo and catering to middle and upper-class families. The group of subjects consisted of twelve two-year-old children who had never been to school before and who had never been exposed to a second language.

The data was produced by recording the daily routine in this classroom, given that the conflicts could not be predicted. The researcher would leave the camera on the table or in a chair in the corner of the classroom at the beginning of the day which served to record absolutely everything until the battery went dead. This procedure helped to ensure the recording of natural, unexpected daily conflicts. After the collection of the data, some episodes were selected according to the type of dispute and chronologically so as to highlight the development of the participants throughout the school year. Out of over two hundred video recordings, only ten were analyzed for the Master's thesis. For this article, one episode was chosen in order to elucidate the multicultural development of the children. A first episode is reported to make it possible for readers to better understand the nature of the conversation that took place among the kids in the main episode.

In the first episode, Gazzotti dramatizes a situation in which she has a bag of biscuits, and a puppet crocodile, which is playing with her, has none. The crocodile then must discover an effective way to get some biscuits for himself and comes up with the sentence: "May I have one, please?", in turn obtaining a biscuit after resorting to such a linguistic tool. After having told that story, the teacher created a new scene and invited the students to play with her. In this new scene, the crocodile was the one with the bag of biscuits and the children had to ask him for one. Kids who wanted a biscuit should go near the crocodile and ask - "May I have one, please?" - with the teacher's help if necessary. This is a moment of controlled playtime when all kids are interacting with the teacher, observing the crocodile and playing with it. 
The second episode, which is the focus of this article, shows the kids during their own snack time at school. It is a free activity when they interact without the teacher's controlled intervention. Students are eating their snacks brought from home. They are all sitting at three tables of four seats each, joined together. At one of the tables there are four children sitting together: Augusto, Enzo, Rodrigo and Maria Clara. Augusto wants one of Enzo's crackers but does not know how to get that. He then starts a conversation about putting things on Enzo's napkin. Maria Clara, who is sitting in front of these boys and has been observing their dialogue, stands up, goes near the two boys and asks: "May I have one?", pointing to a cracker Enzo had on his napkin. As soon as Enzo reaches to give her the cracker, she turns to Augusto, saying: "See? He gave me one!" trying to show him how he should ask for the cracker. Augusto decides to try, but he makes his request in Portuguese, saying: "Me dá um?". Enzo just stares at Augusto, with no response. Maria Clara looks at Augusto and says; "Say! May I have one?". Rodrigo, who was sitting with them and listening to this conversation, decides to ask for one for himself, saying: "May I have one?" At the same time, Augusto also asks, this time in English: "May I have one?" and Enzo ends up giving them both a piece of cracker.

The data transcription of the second episode, which is the one of conflict, was based on a multimodal perspective, taking into consideration not only the verbal aspects, but also gestures, facial expressions and tone of voice. The analysis was done with the aid of the model called Collaborative Tension, developed by Oliveira (2006), which consists of three broad categories, as defined below.

The Tension Generating Utterance is normally created through questions, usually made by the educator, with the goal of making children reflect upon the conflict situation (dispute). The Collaborative Tension consists of the argumentative situation between teacher-students and between students in order to try to solve the conflict. The Transformative Action is when, after the sharing and negotiating of meanings and sense, one of the students acts collaboratively, solving the dispute in question.

\section{Multiculturality - Being and Becoming}

Multicultural Education involves the teacher's ability to allow students' multiple voices to remain at play and to speak for themselves in the multilingual and multimodal manners they find available to them. To accomplish this, students must be motivated and introduced to multiple forms of acting in the world through a variety of activities, games, conversations, and 
moments of free and controlled playtime. In the context of this research, as reported by Gazzotti (2011), kids had opportunities to express themselves whenever dealing with a conflict and learning to argue collaboratively became the most important learning point of that school activity.

As briefly mentioned in the introduction of this article, what motivated Gazzotti (2011) to begin the research was the fact that school teachers do not have enough time to work on conflict resolution due to the many other school contents they must deal with. Bearing this in mind, the teacher-educator first aimed to work with conflicts and then with the other school contents. Since the disputes happened quite frequently in the classroom, in the playground, during snack time, bathroom time, music class and so on, whenever they happened, children were all invited to think about possible solutions to such conflicts.

The discussions happened in many different moments in the school routine, as well as different approaches to the same subjects, such as:

- during circle time: through dramatization, stories and listening to one another;

- at the time of the conflict: using the Tension Generator Utterance as a starter to the reflection process;

- in the classroom: through controlled games leading children to use argumentative tools to play as well as through role plays and performances of real-life social activities;

- in the playground: through games with the teacher and group discussions; etc.

After going through the same kind of experience when solving conflicts, it became part of the group identity to sit and discuss when dealing with problems, as can also be seen in this brief extract.

The data produced and analyzed in Gazzotti's research (2011) showed that children were indeed able to act collaboratively and autonomously when solving conflicts after experiencing a collaborative and argumentative environment for a year at school. It also showed that the subjects were constituting themselves bilingually, since they resorted to both languages to express themselves. The results provided evidence of how these kids managed to develop new forms of interacting to solve problems.

In the example that follows, we would like to focus on the multicultural perspective of these means of solving problems and how this is collaboratively constructed. As stated above, the dispute focused on in this article occurred during a free moment when children regulated themselves with the aid of their 
friends. Out of the multiplicity of actions they could have turned to at this point, they turned to something they had internalized from previous experience and they resorted to multiple modes and multiple languages in other to solve their conflict. Moreover, they felt they could rely on each other to solve the problem and to find a means of achieving their desired aim.

The brief extract below, taken from the second episode mentioned above, will help illustrate the free-interaction between the children during their snack time.

\begin{tabular}{|c|c|c|c|c|c|}
\hline Time & Turn & \begin{tabular}{|l|} 
Participant \\
\end{tabular} & Original Lines & Translation & $\begin{array}{l}\text { Description of gestures, facial } \\
\text { expressions and tone of voice }\end{array}$ \\
\hline \multirow[t]{3}{*}{$7 ’ 44$} & 1 & Augusto & $\begin{array}{l}\text { Por no seu } \\
\text { napkin. }\end{array}$ & $\begin{array}{l}\text { Put it on your } \\
\text { napkin. }\end{array}$ & $\begin{array}{l}\text { Sticks his arm out and places his finger } \\
\text { on Enzo's napkin. He speaks with a low } \\
\text { voice, with his eyes down and with one } \\
\text { hand putting a piece of bread in his mouth. }\end{array}$ \\
\hline & 2 & Enzo & $\begin{array}{l}\text { Eu quero... } \\
\text { ponho aqui? }\end{array}$ & $\begin{array}{l}\text { I want... } \\
\text { put it here. }\end{array}$ & $\begin{array}{l}\text { Looks at Augusto in the eye, speaks in a } \\
\text { loud voice and makes strong gestures } \\
\text { with his hand. }\end{array}$ \\
\hline & 3 & Augusto & $\begin{array}{l}\text { Eu quero do } \\
\text { seu napkin. }\end{array}$ & $\begin{array}{l}\text { I want the one } \\
\text { from your } \\
\text { napkin. }\end{array}$ & $\begin{array}{l}\text { Raises his voice a little, pointing gently } \\
\text { again at a certain spot of the napkin which } \\
\text { is on the table. Right after speaking, he } \\
\text { looks up to the person recording (who } \\
\text { was not the teacher) without raising his } \\
\text { head, just his eyes. }\end{array}$ \\
\hline \multirow[t]{6}{*}{$8 ’ 04$} & 4 & Maria Clara & $\begin{array}{l}\text { May I have } \\
\text { one? }\end{array}$ & $\begin{array}{l}\text { May I have } \\
\text { one? }\end{array}$ & $\begin{array}{l}\text { Stands up, goes around the table in order } \\
\text { to get closer to Enzo, reaches up to him, } \\
\text { bends her body over a bit along with her } \\
\text { head and sticks out her hand, with her } \\
\text { palm facing up, making a shell. After that, } \\
\text { she uses one finger to point to the biscuit } \\
\text { and then goes back to making a shell } \\
\text { with her hand. }\end{array}$ \\
\hline & 5 & Enzo & Esse? & This one? & $\begin{array}{l}\text { Looks at Maria Clara, looks at his } \\
\text { biscuits, points gently and looks back } \\
\text { at her to make the question. }\end{array}$ \\
\hline & 6 & Maria Clara & $\begin{array}{l}\text { Viu? Ele dá! } \\
\text { Olha, ele deu! }\end{array}$ & $\begin{array}{l}\text { See? He shares! } \\
\text { Look, he gave } \\
\text { me one! }\end{array}$ & $\begin{array}{l}\text { Puts her body up straight, looks at } \\
\text { Augusto and shows the biscuit in her } \\
\text { hand. She speaks in a loud, warm voice. }\end{array}$ \\
\hline & 7 & Augusto & Me dá um? & Can I have one? & $\begin{array}{l}\text { Turns his body to Enzo (who is already } \\
\text { sitting next to him) curving his body a } \\
\text { little, bending his head and making a shell } \\
\text { with his hand, just like Maria Clara had } \\
\text { done. He makes his request in a low voice. }\end{array}$ \\
\hline & 8 & Enzo & - & silence & $\begin{array}{l}\text { Looks at Augusto's face with his head } \\
\text { leaning down a little. }\end{array}$ \\
\hline & 9 & Maria Clara & $\begin{array}{l}\text { Fala: May } \\
\text { I have one? }\end{array}$ & $\begin{array}{l}\text { Says: May } \\
\text { I have one? }\end{array}$ & $\begin{array}{l}\text { Straightens her body and increases her } \\
\text { voice, trying to look at Augusto's face } \\
\text { over Enzo's head. }\end{array}$ \\
\hline
\end{tabular}




\begin{tabular}{|c|c|c|c|c|c|}
\hline & 10 & Rodrigo & & & $\begin{array}{l}\text { Gets into the conversation. He approaches } \\
\text { Enzo, standing up, bending his body a } \\
\text { little and sticking out his hand, making a } \\
\text { shell with his palm. He does not say } \\
\text { anything. }\end{array}$ \\
\hline & 11 & Augusto & $\begin{array}{l}\text { May I have } \\
\text { one? }\end{array}$ & $\begin{array}{l}\text { Before giving } \\
\text { Enzo time to } \\
\text { respond to } \\
\text { Rodrigo's request: } \\
\text { May I have one? }\end{array}$ & $\begin{array}{l}\text { Gets even closer to Enzo, bending his } \\
\text { body a little more, bending his head } \\
\text { enough to be able to look at Enzo in the } \\
\text { eye. Puts his hand out, making a shell } \\
\text { with his palm. }\end{array}$ \\
\hline & 12 & Enzo & & & $\begin{array}{l}\text { Looks at Augusto calmly and gently gives } \\
\text { him the biscuit. }\end{array}$ \\
\hline 8'15 & 13 & Rodrigo & $\begin{array}{c}\text { May I have } \\
\text { one? }\end{array}$ & $\begin{array}{l}\text { May I have } \\
\text { one? }\end{array}$ & $\begin{array}{l}\text { Remains in the same position, stretching } \\
\text { his arm a little more and placing it in } \\
\text { front of Enzo's eyes. }\end{array}$ \\
\hline & 14 & Enzo & & & $\begin{array}{l}\text { Looks at Enzo calmly and gently gives } \\
\text { him the biscuit. }\end{array}$ \\
\hline
\end{tabular}

In the process of getting a biscuit, Enzo, Augusto, Maria Clara and Rodrigo exercised multiple ways of interacting and acting in the world to solve a problem. The initial conflict triggered by the desired articulated by Augusto's expressions and gestures in relation to Enzo's biscuits was finally solved with the help of Maria Clara's suggestions and performances of how to achieve the desired goal. This was done in a multimodal, multilingual and multicultural way which could be seen by the way they interacted in this brief episode.

In this excerpt, the Tension Generator Utterance, which is expressed in Augusto's initial turn and goes up to turn 3, conveys his wish to get Enzo's biscuit. His longing is expressed by his look, his gestures and his sentence, while the tension is stressed by the fact that, at a certain point, he resorted to looking at the person with the camera - the adult - in an attempt to show his need for help. At this point, it is possible to see that the conflict demands from him more than he could do by himself. At this dramatic moment, when the desire for the biscuit clashes with his friend's lack of the desired response - giving him what he wanted, Augusto could have resorted, as many usually do, to grabbing the food even without permission, to crying, to biting his friend, to asking the teacher for help. Here, however, there is a break with this common pattern among two-year-old kids. In turn 4, Maria Clara realized there was a problem and acted willingly and collaboratively in order to help Augusto, who could not solve the problem by himself, by setting an example for him.

To do that, Maria Clara used a number of multimodal resources: she moved around the room to get closer to those involved, touched her friend, stuck her hand out, made a shell with her hand to physically complement her 
verbal request, pointed to the biscuit, reinforcing the object of desire and, above all, used the expression kids and teacher had been working on recently: "May I have one?". The performance worked out by Maria Clara expressed her understanding of the social rules of her context in relation to how to participate in the social activity of sharing food during snack time. She showed her multicultural resources in dealing socially, physically, linguistically and emotionally with the process. By doing so, she set an example which was successfully understood by Enzo who, after questioning about which biscuit she wanted, gave it to her.

Moreover, Maria Clara not only set the example and got the biscuit she wanted, she turned and looked directly at Augusto and triumphantly explained to him that Enzo had given it to her, stating that "he shares". In the Collaborative Tension created both by her example, as well as by her comment, gesture and look, a ZPD was established for all those involved. The kids began to act beyond their immediate possibilities and limits to receive the things they wanted not only for themselves, but also for the others. Augusto, for once, was able, with Maria Clara's collaboration, to verbally express his desire for the biscuit, which he seemed not to be able to do by himself previously. In collaboration, they connected and acted to create new possibilities of achieving desired aims together; therefore, both Augusto and Maria Clara expanded their interactional abilities - Augusto by being able to communicate his desire and obtain what he wanted by doing so and Maria Clara by being able to mediate a situation between peers using argumentative and socially built tools. Maria Clara was happy to exemplify a way for Augusto to go beyond his limitations. She did not get the biscuit for him. She showed him how to do that, using different cultural tools. She was also able to externalize a linguistic tool ("May I have one?") she had learned in order to manage a situation that she had to realistically deal with. She even helped her peer to operate with those tools by telling him, to say the same expression she said (turn 9).

When Augusto followed Maria Clara's example and said in Portuguese (Me dá um?), he resorted to a cultural possibility also available to him, which showed his understanding and mastery of the social situation as well. However, Enzo seemed not to accept this as a possibility. To that, Maria Clara, once again gave support, reminding August by using the imperative in Portuguese: Fala (Say) and the expression they had been learning: "May I have one?".

This pattern of collaboration establishes a basis for transforming not only Augusto's actions, but also Rodrigo's, who moved from his place to ask 
for a biscuit as well. However, aware of the social and linguistic role he was expected to perform, Augusto multimodally assumed the turn by saying "May I have one?", making a shell with his hands as he had socially experienced earlier, getting closer to Enzo and looking him in the eyes. By following exactly what Maria Clara had done previously, he created a performance which would make it possible for Enzo to provide the desired response.

This is an example of how children had internalized the cultural methods of reasoning they had been exposed to throughout the school year, such as resorting to argumentation to try to solve a certain situation. The collaborative tension was set and developed by children only, with no intervention from the educator whatsoever and, by themselves, they figured out a way of (i) expressing verbal desire for the biscuit (turns 4, 6, 9); (ii) establishing multimodal communication (turns 1 through 12); (iii) willingly offering help to a peer who was having difficulties to operate with the social tools he had been provided (turns 4,6,9); and finally (iv) collaboratively transforming the conflict situation into the transformative action (turns 11, 12, 13 and 14). The relationship kids created with each other was essential to their multicultural development.

In a collaborative multicultural context such as this, ZPDs were created and the conflict resolution processes turned out to be identity developmental processes as well. When kids see they can find multiple ways of dealing with conflict, they can resort to different tools; they can count on each other to find solutions to their simple problems; they become more resilient subjects who can find and create different mediating tools to transform situations, the context and the environment. The use of gestures, facial expressions, tone of voice and verbal expressions in different languages became a multiplicity of resources for generating meaning and solving conflict. Different types of semiotic devices were also used for social action and as means through which to display mutual orientation in quite different ways of performing in a juxtaposition of multiple expressions which constitute not only the actions performed by the subjects, but also who these subjects are becoming.

\section{Practical and theoretical implications of this study for Multicultural Education}

This article aimed to investigate the implications and affordances of the bilingual school environment for the children's process of multicultural development. Departing from a social-historical-cultural viewpoint, this 
study believes that the constitution of subjects is directly linked to the socialhistorical-cultural environment in which they are brought up and inserted, that is, to the relationship they establish with other subjects and with the environment itself.

The fundamental role of language in social interaction for the psychological development of children was also crucial in arguing and explaining the importance of the educator's intervention in the multicultural development of those involved. The concepts of the dialogical constitution of subjects (Bakthin, 1981), the internalization of tools and the development of higher mental abilities (Vygotsky, 1934) proved to be essential to clarify how children learn to be/to become and how experiences that were once shared in the social environment eventually become an inner cultural way of reasoning, thus granting the environment great responsibility in building subjectivity.

This article argues that school may play a formidable role in the development of critical reflexive subjects, given that the voices of such an environment, as well as the multicultural and multimodal experiences lived in it, are internalized by young children and eventually become part of their inner selves. The example briefly studied here shows how children have internalized the social tools provided by the school environment and how they turn to such tools when dealing with a real life situation. In doing so, we are led to believe that there was indeed a multicultural development, first because the children involved are acting according to what their previous experience had shown to be successful, and second, because they are doing so multilinguistically. In the data discussed, for example, children are clearly relying on episodes, such as the controlled playtime discussed in this article in which children had to resort to linguistic tools to obtain cookies from the crocodile. Such controlled playtime activity created resources for kids to rely on. Through experience, children showed they had learned a new possibility of how to be/act in the world, transforming the environment (overcoming a conflict) as well as themselves.

As in the definition of ZPD defined in this article, the previously analyzed excerpt showed that what was once done between children and educator, that is, interpsychologically, was now done intrapsychologically, because the experience had become part of the children's repertoire of social and linguistic possibilities. Maria Clara appears to have mastered the cultural aspects of the social experience and forms of social behaviour and, by acting in accordance with them, created a new ZPD for the entire group and a new 
interpsychological experience for her friends where she acted as a more experienced peer.

For kids to expand their horizons of multimodal possibilities of acting linguistically or otherwise, it is essential that educators provide students with opportunities to experiment with multicultural ways of dealing with conflicts and life experiences in general using the resources that they have access to.

Multimedia, multimodal, multifunctional and multidimensional perspectives of thinking and acting could be collectively expanded in the discussed example. Kids went beyond themselves to find ways to participate not only in the snack time activity and in the sharing activity, but also in the activity of helping each other to solve and deal with conflicts. The two-yearold kids relied on the fact that they could use more than one language (Portuguese and English) and different modes (pointing, looking or touching) to solve or achieve their aims (getting the biscuit, teaching a way of acting, asking for something).

In the data presented, we can clearly see that multiple actions (such as talking, pointing, acting in order to serve as an example for others), multiple languages (Portuguese, English) and multiple modes (lower voice, higher voice, position of the body, eye contact) were used together in a multicultural perspective to transform the situation of 'not having biscuits'. As proved by Gazzotti's (2011) studies the same kind of situation would not have produced such an outcome without some kind of social intervention. The collaborative transformation of the environment, the situation and the subjects displayed in the data shows children going beyond their real development and their immediate possibilities and reaching a new co-built proximal development.

In addition, these multiple interconnections expanded their possibilities for future choices of actions, creating a perezhivanie. That is, they generated an emotional-cognitive experience in which kids could experiment with emotions and possible ways of being while learning a plurality of things that could be useful tools for them to act in the world they are creating and which is creating them.

When these kids see they are not only responsible for themselves, but can also contribute to creating a collaborative environment as well as to formulating a wider transformation of reality, the complexity of teaching-learning situations changes drastically to include the development of social selves.

The school environment enables the establishment of a collective ZPD, giving all participants the opportunity to go beyond the limitations of their 
own direct experience and to build new socially shared knowledge. When that happens, all participants may reach new levels of development. To live, understand and learn from an experience, it is necessary to move away from it and go beyond it. It is essential to develop what Vygotsky (1932, p. 241) called the feelings of we. In a collective ZPD, students and teacher may experience, through multicultural perspectives, multiple possibilities of acting, thinking and being.

For this to be possible, in the example provided here, emphasis was placed on multifunctional and multidimensional ways in which very young kids started to find a means through which to solve disputes and collaborate with their colleagues in order to help them solve their disputes with others. Many other examples could be used and should be researched. If we are constituted within historical, cultural contexts of the social interactions we live by and in the languages we are immersed in, it seems to be vital that we create a greater myriad of possibilities for the development of future opportunities of being for each and every individual.

As the data analysis and the discussion of the theoretical background has shown, when children are presented to a multicultural, multimodal and multilinguistic environment, especially at a very young age, they are introduced to brand new ways of being and becoming, which enables them to act in such a way as to transform unsatisfying situations. If, at a very early age, such subjects can reflect, act and transform (the environment, themselves and others), such an educational framework may well enhance the possibilities of developing a more open-minded, diverse, integrated, multicultural future society.

\section{References}

BAKHTIN, M. Questóes de Literatura e de Estética: A teoria do romance. Translation by A. F. BERNADINI, J. P. JR, A. Góes Junior, H. S. Nazário, H. F. de Andrade. São Paulo: Editora UNESP: HUCITEC, 1998.

BAKHTIN, M.; VOLOCHÍNOV, V. N. Marxismo e filosofia da linguagem. Translation by Michel Lahud and Yara Frateschi Vieira. São Paulo: Hucitec, 2002. COPE, B.; KALANTZIS, M. "Multiliteracies": New Literacies, New Learning. Pedagogies: An International Journal. vol. 4, issue 3, 2009. p. 164-195. Available at: <http://www.informaworld.com/smpp/title $\sim$ content $=$ t775653691>. Accessed July 26, 2013. 
DEWITT, S. Multicultural democracy and inquiry pedagogy. In: Intercultural Education. vol. 14, Issue 3, Reino Unido UK. 2003. p. 279-290. Disponível em: http://www.tandfonline.com/doi/abs/10.1080/1467598032000117079\#. UzjuP_ldXtk Acessed: 26 Fev 2014.

GAZZOTTI, D. Resolução de Conflitos em Contextos de Educação Infantil Bilingue. (Masters Thesis in Linguistics Applied to Language Teaching). São Paulo: Pontifícia Universidade Católica de São Paulo, 2011.

GOODWIN, C. Action and Embodiment within situated human interaction. In: Jornal of Pragmatics. v.32, Los Angeles, 2000. p. 1489-1522 Disponível em <www.sscnet.ucla.edu/clic/cgoodwin/00act_body.pdf> Acessed: 27 Fev 2014. KRESS, G. Multimodality In: COPE, B.;KALANTZIS, M. (Orgs.) Multiliteracies - Literacy Learning and the Design of Social Futures. New York: Routledge, p. 182-234, 2006.

KRESS, G.; VAN LEUWEN, T. Reading images: the grammar of visual designs. $2^{\text {nd }}$ ed. New York: Routledge. 2006.

LEITÃO, S.; BANKS-LEITE, L. Argumentação na linguagem infantil: algumas abordagens. In: DEL RÉ, A. (Org.). Aquisição da Linguagem: Uma Abordagem Psicolingüistica. São Paulo: Contexto, 2006.

LIBERALI, F. C. Multiculturalidade, multimodalidade e desencapsulação curricular, (article in progress).

LIBERALI, F. C.; Formação Crítica de Educadores: Questôes Fundamentais. Volume 01. Taubaté: Cabral Editora e Livraria Universitária, p. 112, 2008.

MAGALHAES, M. C. C.; LIBERALI, F. Negotiation in Teacher Education Programs. In: First Iscar Congress, Sevilla, Book of Abstracts iscarservilla - Negotiation in Teacher Education Programs, v. 1. Sevilla: Akron Gráfica, 2005. p. 272-273.

NEWMAN, F. \& HOLZMAN, L. Lev Vygotsky: revolutionary scientist. New York: Routledge, 2002.

RIBEIRO, R. M. A construção da argumentação oral no contexto de ensino. São Paulo: Cortez, 2009.

SANTOS, B. S. A gramática do tempo: para uma nova cultura política. São Paulo: Cortez, 2008.

THE NEW LONDON GROUP. A pedagogy of multiliteracies: Designing social futures. IN: COPE, B.; KALANTZIS, M. Multiliteracies: Literacy Learning and the Design of Social Futures. New York: Cambridge. p. 9-37, 2000.

VYGOTSKY, L. S. (1933-1935). A Formação Social da Mente: O Desenvolvimento dos Processos Psicológicos Superiores. São Paulo: Martins Fontes, 1998. 
VYGOTSKY, L. S. (1929). The Problem of The Cultural Development of the Child. Available at: <http://www.marxists.org/archive/vygotsky/works/1929/cultural_ development.htm>. Accessed July 26, 2013.

VYGOTSKY, L. S. (1932). On the problem of the psychology of the actor's creative work. In: RIEBER, R. W. (ed.) The collected works of L.S. Vygotsky, vol. 6, Scientific legacy. New York, Boston, Dordrecht, London, Moscow: Kluwer Academic/Plenum Publishers, 1999. p. 237- 244.

VYGOTSKY, L. S. (1934a). Pensamento e linguagem. $4^{\text {th }}$ ed. São Paulo: Martins Fontes, 2008.

VYGOTSKY, L. S. (1934b). The problem of the environment. Available at: <www.marxists. org/archive/.../environment.htm> Accessed July 28, 2013.

Data de submissão: 30/07/2013. Data de aprovação: 11/01/2014. 